\title{
Source Apportionment and Risk Assessment of Polycyclic Aromatic Hydrocarbons in Black Carbon Monitored in Port Harcourt, Rivers State, Nigeria
}

\author{
Muhyideen Oloyede ${ }^{1}$, Precious Nwobidi Ede ${ }^{2}$ \\ ${ }^{1}$ Institute of Geoscience and Space Technology, Rivers State University, Port Harcourt, Nigeria \\ ${ }^{2}$ Department of Geography and Environmental Management, Rivers State University, Port Harcourt, Nigeria
}

\begin{abstract}
The purpose of this study was to determine concentrations of polycyclic aromatic hydrocarbons (PAHs) in air samples in Port Harcourt metropolis, Rivers State, Nigeria, evaluate their potential risks to human health and identify pollution sources by characterizing the PAHs. Sixteen polycyclic aromatic hydrocarbons were measured with a total concentration range of 0 to $9,589 \mathrm{mg} / \mathrm{kg}$ in the rainy season and 0.46 to $131 \mathrm{mg} / \mathrm{kg}$ range in the dry season. High molecular weight PAHs dominated the PAH profiles accounting for $91 \%$ in dry season and $45 \%$ in the wet season. The overall assessment of the ratios of LMW to HMW of minimum, maximum and mean concentrations indicated pyrogenic sources. Benzo (a) pyrene equivalent (BaPeq) analysis showed that benzo (a) pyrene, DiBenzo $(\mathbf{a}, \mathrm{h})$ antracene and Indeno (1.2.3-cd) pyrene contributed the highest cancer toxicity with $94 \%$ and $85 \%$ in wet and dry seasons, respectively. The total incremental lifetime cancer risks of PAHs ranged from 0 to 4.90 with a median value of $3.37 \times 10^{-2}$ in wet season; while in the dry season, ILCR of PAHs ranged from $1.62 \times 10^{-5}$ to $7.42 \times 10^{-3}$ with a median value of 1.15 $x 1^{-3}$. These values showed pervasive pollution indicating a major carcinogenic risk of PAHs. Mean ILCR in wet season was $3.37 \times 10^{-2}\left(33,700 \times 10^{-6}\right)$ meaning 1 in every 30 persons in the study area is estimated to develop cancer. In the dry season, mean ILCR was $1.15 \times 10^{-3}\left(1,150 \times 10^{-6}\right)$ meaning 1 in every 870 persons in the study area is estimated to develop cancer.
\end{abstract}

\section{INTRODUCTION}

Polycyclic aromatic hydrocarbons (PAHs) are organic compounds containing two or more benzene rings bonded in linear, cluster, or angular arrangements (Abdel-Shafy \& Mansour, 2016). There are hundreds of different PAH congeners but U.S. EPA selected 16 PAH congeners as "priority pollutants" (Nisbet \& Lagoy, 1992; Kamal et al., 2016). These 16 PAHs are selected as the priority pollutants due to their frequency or risk by the U.S. Environmental Protection Agency (USEPA, 1993). These environmental pollutants compounds are widely distributed in the air, water, and soil according to Honda and Suzuki (2020) who also hold that they are categorized as general environmentally harmful pollutants which according to Yang et al. (2014) are introduced into the environment from both natural sources like oil seeps, forest fires and volcanic activity; and anthropogenic sources like petrochemical industrial effluents, coal tar processing wastes and combustion processes.

$\mathrm{PAH}$ is an important pollutant contained in black carbon that are widely studied due to possible cancer and non-cancer risks it poses to its receptors particularly human. As particulate soot they are formed after incomplete combustion of carbon containing materials according to Niranjan and Thakur (2017) who regarded it as unwanted powdery mass of fine black particles. Gasphase soot contains polycyclic aromatic hydrocarbons (Omidvarborna et al., 2015).

Port Harcourt, the largest city in Rivers State and other settlements in that region of Nigeria suffer severe exposure to air pollution due to various industrial and nonindustrial operations and processes. A study showed that the impact of air pollution is highest on Port Harcourt among the 16 communities in the Niger Delta whose air samples were analysed (Ede \& Edokpa, 2105). In addition, since November 2016, residents of Port Harcourt and its environs have been experiencing discernible soot emissions in the atmosphere. The aim of this research is to analyse the PAHs contents of the samples and determine the concentrations for two seasons; identify the potential sources of PAHs diagnostic ratio analysis; and assess the carcinogenic risks of the particulate soot in the study area.

\section{MATERIALS AND METHODS}

Previous study by Ede and Edokpa (2017) has shown that the soot seen in Port Harcourt comes from outside the metropolis and that it is uniformly propagated over the city. Five sampling locations evenly spread across the city were therefore used in this study and air samples were collected during the day and in the night. The Air Metrix Minivolt Active Sampler (SN 3018 ver 4.2 10/01/02 by Environ Technology Services PLC 13028) was used to suck soot directly on to filters. The soot collected onto the filter was analysed in the laboratory for 16 priority pollutant PAHs.

In week one and two, samples were collected in both day and night. In each of the 5 sampling locations (L1 to L5), four samples were taken after every 6 hours and a total of 20 samples taken for the wet season and the sampling procedure was repeated for dry season. Each of these 40 samples were analysed for 16 U.S. EPA priority PAHs. The PAHs are naphthalene (Nap), acenaphthylene (Acy), acenaphthene (Ace), fluorine (Flu), phenanthrene (Phe), 
anthracene (Ant), fluoranthene (Fla), pyrene (Pyr), benzo(a)anthracene (BaA), chrysene (Chr), benzo(b)fluoranthene $(\mathrm{BbF})$, benzo $(\mathrm{k})$ fluoranthene $(\mathrm{BkF})$, benzo(a)pyrene $(\mathrm{BaP})$, indeno( 1,2,3-cd)pyrene (IcdP), dibenzo(a,h) anthracene (DBA), benzo(ghi)perylene (BghiP). The filter was treated with $10 \mathrm{ml}$ of dichloromethane in a $2 \mathrm{oz}$ S/S Jar Amber bottle and agitated automatically with Orbital Genie for an hour. Then the extract was concentrated to below $1 \mathrm{ml}$ by exposing it under a fume hood above it to reduce loss of the semivolatile PAHs due to evaporation and then brought back to $1.0 \mathrm{ml}$. The final extract was analysed for the 16 pollutant PAHs above and calibration curve was plotted for each PAH thereafter.

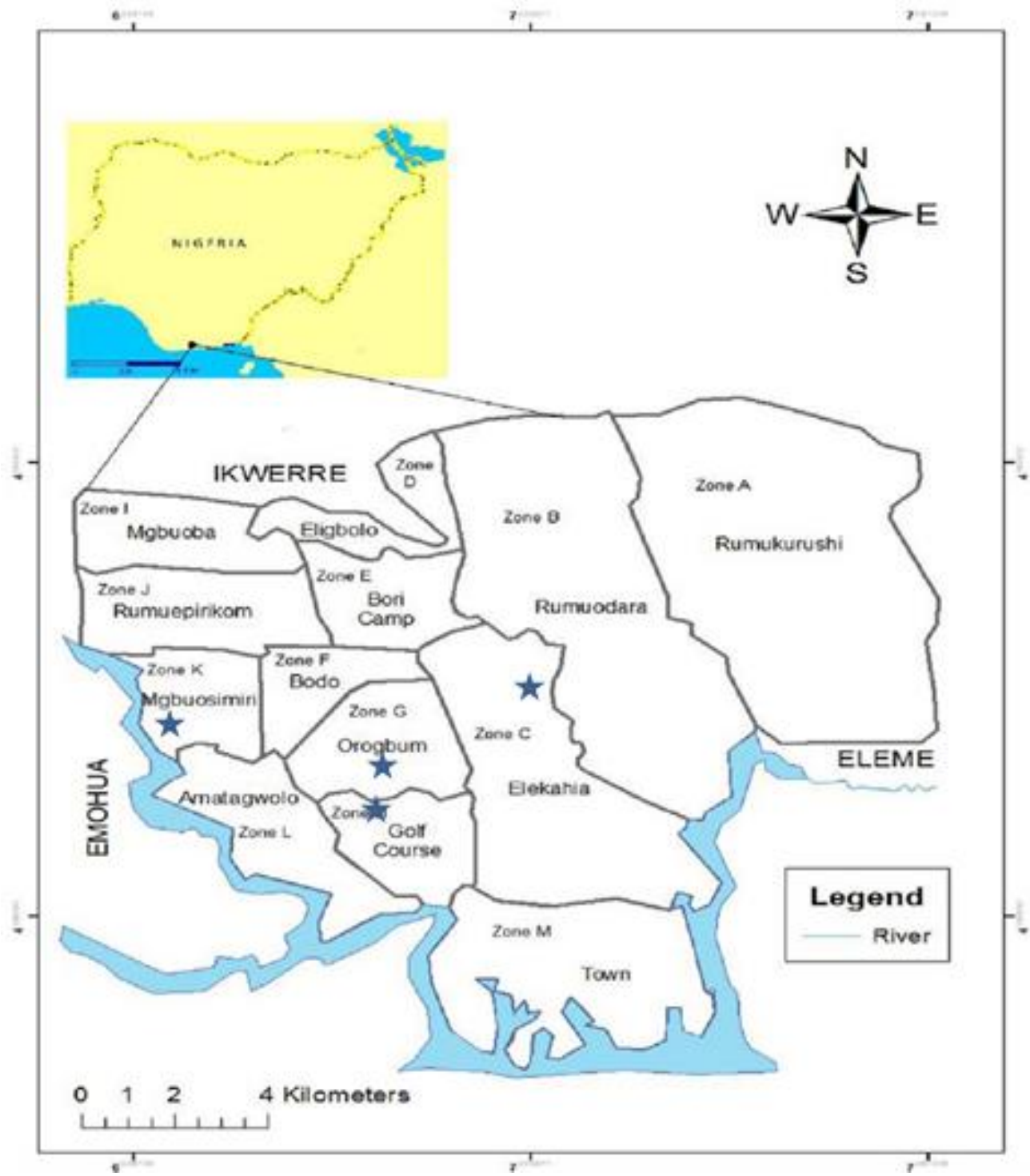

Fig 1:- Port Harcourt, Nigeria: showing the sampling locations Area

\section{PAH Diagnostic Ratios for Source Identification}

PAH diagnostic ratios are commonly used as a tool for identification of PAHs emission sources. The concentration of different PAHs congeners depend on the source from which they are originated. The profile and composition of PAHs reflects the individual source of emission (Wang et al., 2007). PAH diagnostic ratios therefore distinguishes petrogenic and pyrogenic sources of pollution. Also, the emission from petroleum products, petroleum combustion, biomass or coal burning can be distinguished by the diagnostic ratios of the following isomers anthracene \& phenanthrene, and fluoranthene \& pyrene in the combination Ant/(Ant + Phe $)$ and Fla/(Fla + Pyr $)$, respectively. The ratio Fla/(Fla+Pyr $)<0.4$ indicates that the source of PAHs is from petroleum, the ratio between 0.4 and 0.5 implies fossil fuel combustion i.e., liquid fossil fuel, automobile emissions or crude oil. The ratio $>0.5$ indicates grass, wood, coal combustion (De La Torre-Roche et al., 2009). The Ant/(Phe+Ant) < 0.1 indicates petroleum emission source while the ratio > 0.1 indicates combustion (Pies et al., 2008; Tobiszewski \& Namiesnik, 2012). 
ISSN No:-2456-2165

\begin{tabular}{|c|c|c|c|c|c|c|c|}
\hline \multirow{2}{*}{ PAHs (mg/kg) } & \multirow{2}{*}{ Type } & \multicolumn{3}{|c|}{ Wet Season } & \multicolumn{3}{c|}{ Dry Season } \\
\cline { 3 - 8 } & & Minimum & Maximum & Mean & Minimum & Maximum & Mean \\
\hline Naphthalene & LMW & 0 & 2.66 & 0.74 & 0 & 1.1 & 0.15 \\
\hline Acenaphthylene & LMW & 0 & 851.7 & 75.15 & 0 & 0.34 & 0.13 \\
\hline Acenaphthene & LMW & 0 & 606.3 & 64.33 & 0.01 & 1.5 & 0.31 \\
\hline Flourene & LMW & 0 & 957.9 & 116.55 & 0.02 & 1.57 & 0.47 \\
\hline Anthracene & LMW & 0 & 1503 & 248.83 & 0.04 & 1.27 & 0.39 \\
\hline Phenanthrene & LMW & 0 & 39.74 & 6.14 & 0.05 & 2.09 & 0.47 \\
\hline Flouranthene & HMW & 0 & 184.5 & 10.76 & 0.04 & 1.14 & 0.39 \\
\hline Pyrene & HMW & 0 & 707.2 & 69.45 & 0.04 & 1.24 & 0.42 \\
\hline Benz (a) antracene & HMW & 0 & 207.5 & 26.94 & 0.08 & 4.17 & 0.97 \\
\hline Chrysene & HMW & 0 & 43.82 & 4.31 & 0.01 & 6.98 & 1.32 \\
\hline Benzo (b) flouranthene & HMW & 0 & 50.32 & 7.35 & 0.08 & 19.98 & 2.3 \\
\hline Benzo (k) flouranthene & HMW & 0 & 35.73 & 6.71 & 0.05 & 19.4 & 2.73 \\
\hline Benzo (a) pyrene & HMW & 0 & 69.81 & 5.52 & 0.04 & 12.78 & 1.92 \\
\hline DiBenzo (a,h) antracene & HMW & 0 & 1522 & 100.17 & 0 & 6.43 & 1.02 \\
\hline Indeno (1.2.3-cd) pyrene & HMW & 0 & 1653 & 118.58 & 0 & 37.47 & 6.8 \\
\hline Benzo (ghi) perylene & HMW & 0 & 1154 & 71.71 & 0 & 13.71 & 2.33 \\
\hline LMW PAHs & & 0 & 3961.3 & 511.74 & 0.12 & 7.87 & 1.92 \\
\hline HMW PAHs & & 0 & 5627.88 & 421.5 & 0.34 & 123.3 & 20.2 \\
\hline$\Sigma$ PAHs & & 0 & 9589.18 & 933.24 & 0.46 & 131.17 & 22.12 \\
\hline LMW/HMW & & & 0.70 & 1.21 & 0.35 & 0.06 & 0.10 \\
\hline
\end{tabular}

Table 1:- Concentrations of PAHs in the Particle Soot

LMW PAHs denote low molecular weight 2-3 ring PAHs; Nap, Acy, Ace, Flu, Ant and Phe.

HMW PAHs denote high molecular weight 4-6 ring PAHs; , Fla, Pyr, BaA, Chr, BbF,BkF, BaP, DahA, IcdP and BghiP.

High molecular weight PAHs dominated the PAH profiles accounting for $91 \%$ in dry season and $45 \%$ in the wet season. The overall assessment of the ratios of LMW to HMW of minimum, maximum and mean concentrations indicated pyrogenic sources.

\section{Cancer Risk Assessment}

Total benzo (a) pyrene equivalent (BaPeq) of all the 16 PAHs was used in the cancer risk assessment. This is the summation of the product concentration and toxicity equivalent factor (TEF). Presently, over 2 million people live in Port Harcourt and are receptors of soot pollution. The incremental lifetime cancer risk (ILCR) was used to evaluate and calculate the potential risk of PAHs in the soot content of Port Harcourt air. The ILCRs for three pathways of exposures (ingestion, inhalation and dermal contact) were calculated using the following equations (Yang et al., 2014).
- Ingestion

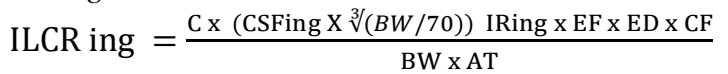

- Inhalation

ILCR inh $=\frac{\mathrm{C} \times(\operatorname{CSFinh} \times \sqrt[3]{(B W / 70))} \text { IRinh } \times \mathrm{EF} \times \mathrm{ED}}{\mathrm{BW} \times \mathrm{AT} \times \mathrm{PEF}}$

- Dermal Contact with Soot

ILCR derm $=$

C x (CSFderm X $\sqrt[3]{(B W / 70)) \text { SA x FE X AF x ABS x EF x ED x CF }}$ BW $x$ AT $x$ PEF

The total risk is given by the sum of risks of ILCRs from direct ingestion, inhalation and dermal contact.

Total ILCRs = ILCR ing + ILCR inh ILCR derm

Where $\mathrm{C}$ is the PAH concentration of soot $(\mathrm{mg} / \mathrm{kg})$ used in calculating benzo (a) pyrene equivalent of each PAHs using their corresponding toxicity equivalent factor (TEF). The carcinogenic slope factor (CSF) measured in $\mathrm{mg} / \mathrm{kg} /$ day was based on the cancer-causing ability of BaP: Cancer slope factor for the three main pathways of 
ISSN No:-2456-2165

exposure are CSFInhalation, CSFingestion and CSFDermal and of $\mathrm{BaP}$ were $3.85,7.3$ and $25 \mathrm{mg} / \mathrm{kg} /$ day, respectively. BW is body weight is $70 \mathrm{~kg}$; AT is average life span of 70 years (default); ED is the exposure duration 30 years and $\mathrm{EF}$ is exposure frequency 350 days per year. IRsoil is the soil intake rate which is $0.0001 \mathrm{~kg} /$ day; IRinh is the inhalation rate which is $20 \mathrm{~m}^{3} /$ day; SA is the dermal surface exposure is $5000 \mathrm{~cm}^{2} /$ day, and $\mathrm{cf}$ is the conversion factor of $10^{6}$; AF is the dermal adherence factor $(\mathrm{kg} \mathrm{cm} 22): 0.00001$ $\mathrm{kg} / \mathrm{cm}^{2}$; ABS is the dermal adsorption fraction of 0.1 and PEF is the soil dust produce factor of $1.32 \times 10^{9} \mathrm{~m}^{3} / \mathrm{kg}$ (USEPA, 1993; Wang et al,. 2007; Peng et al., 2011).

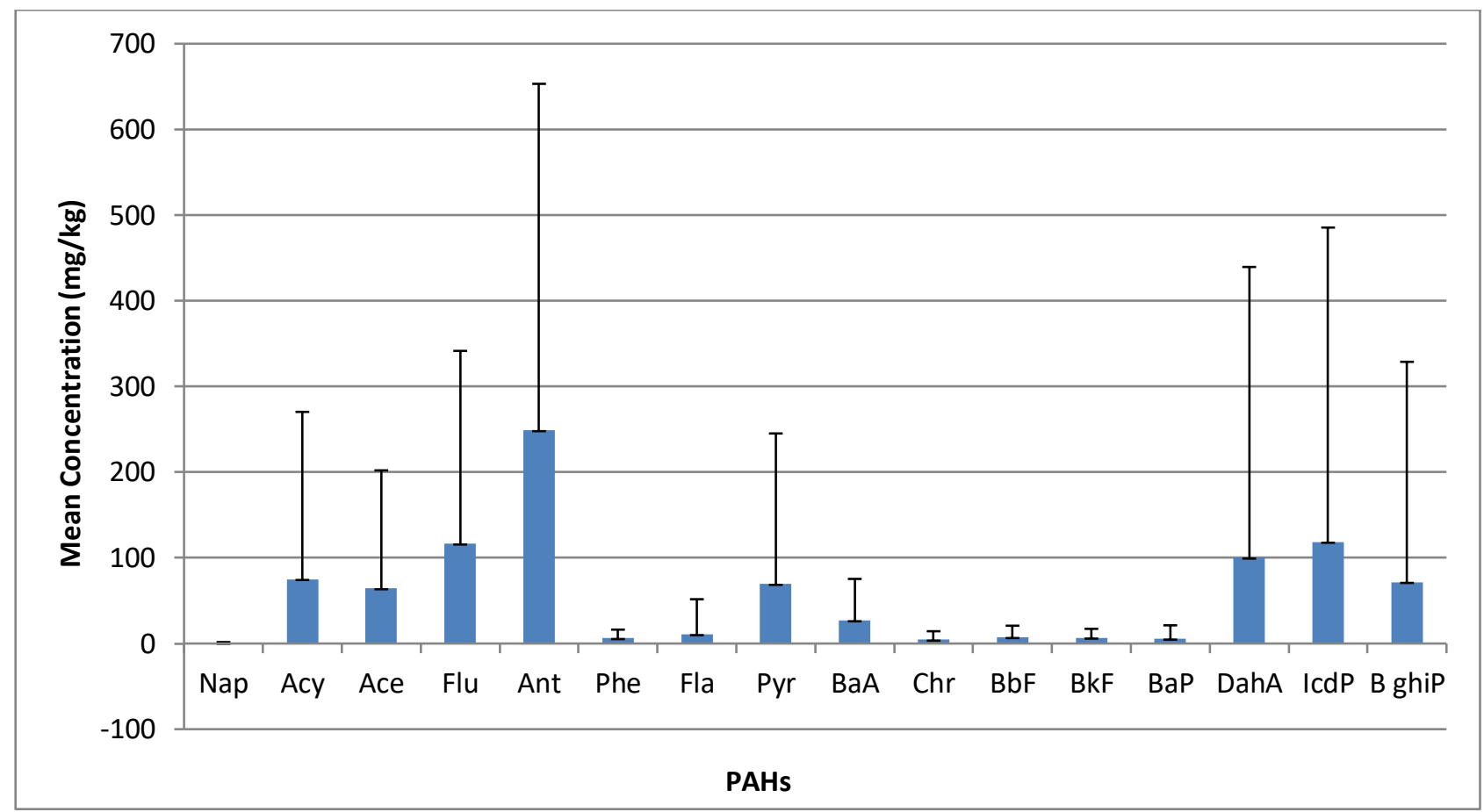

Fig 2:- Mean Concentrations of Individual PAHs in the Wet Season

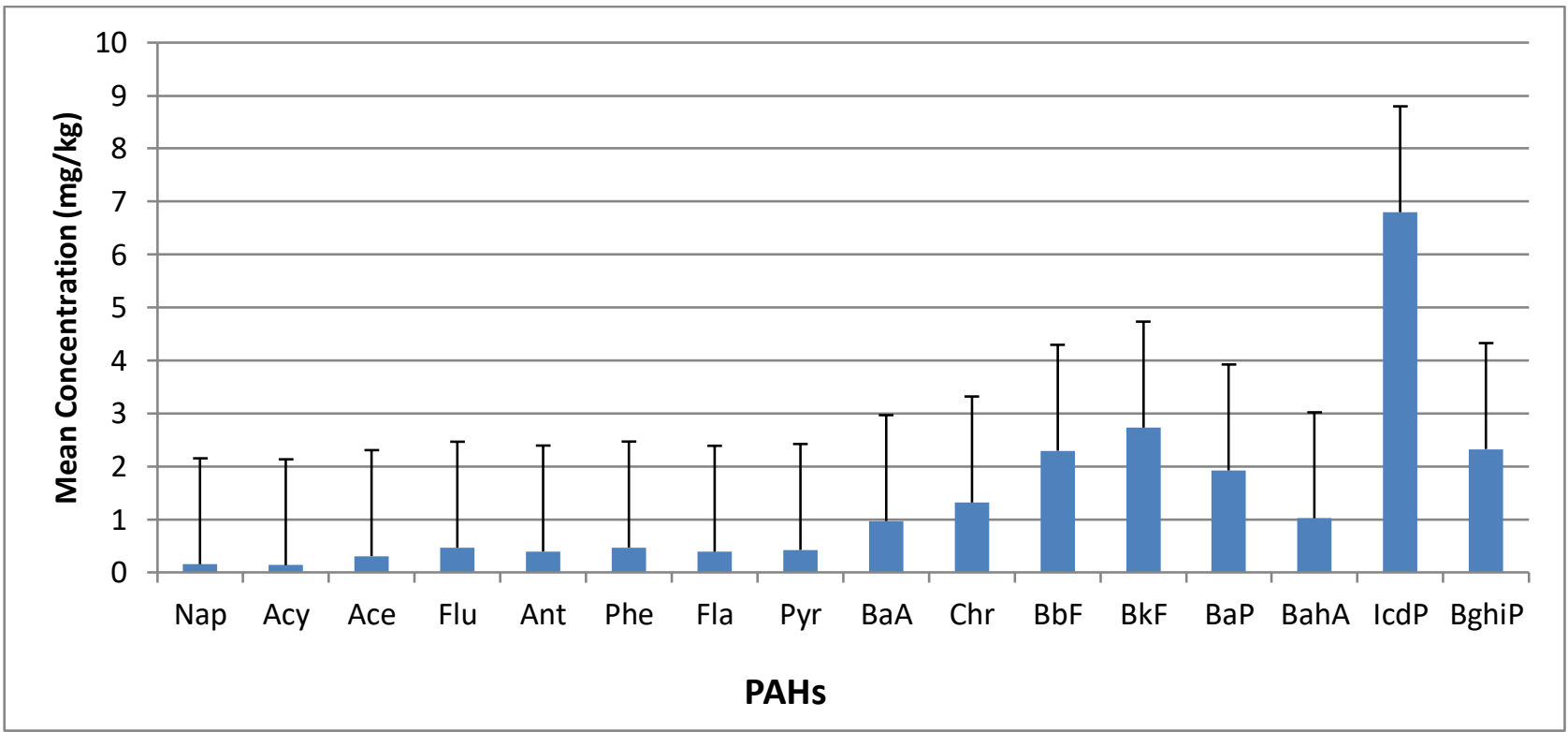

Fig 3:- Mean Concentrations of Individual PAHs in the Dry Season 
ISSN No:-2456-2165

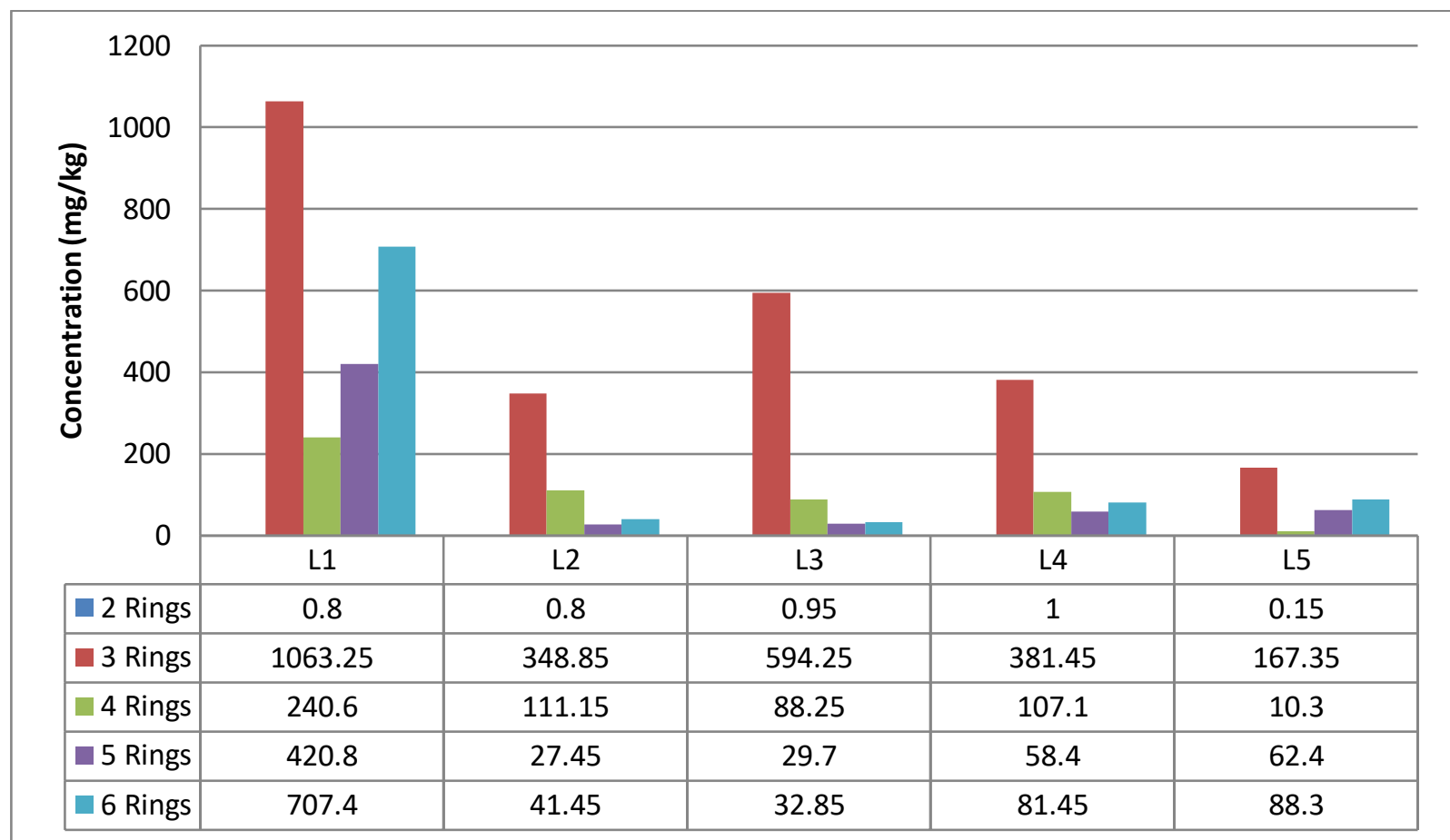

Fig 4:- Frequency Distribution of Different Ring PAHs in Wet Season

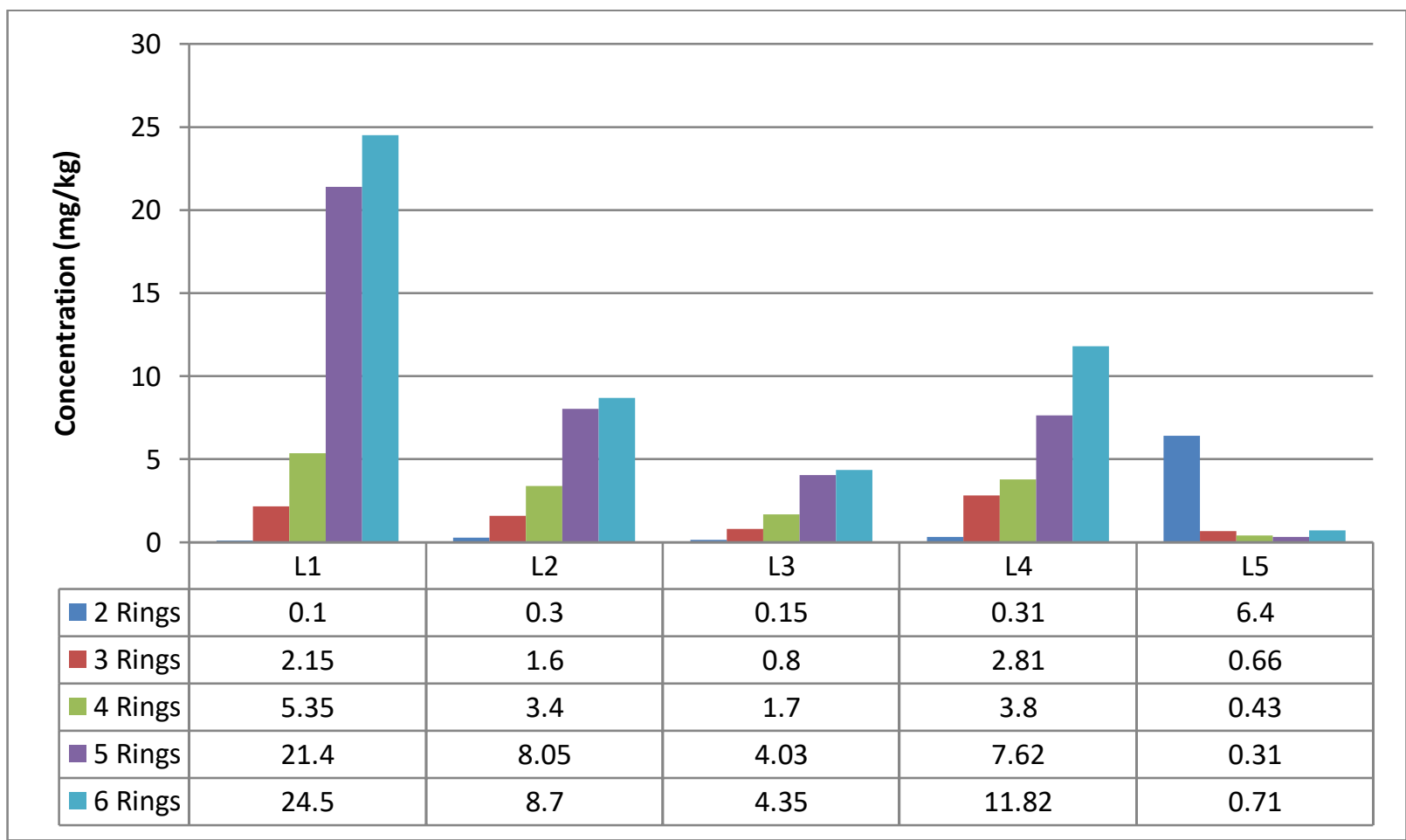

Fig 5:- Frequency Distribution of Different Ring PAHs in Dry Season

\section{RESULTS AND DISCUSSION}

\section{Seasonal PAH Profiles of Soot}

The descriptive statistics for concentrations of PAHs determined in the soot in Port Harcourt is shown in Table 1. The overall total concentration of 16 US EPA priority pollutant PAHs in the atmospheric soot ranged from 0 to $5,589.18 \mathrm{mg} / \mathrm{kg}$ with a mean concentration of $933.24 \mathrm{mg} / \mathrm{kg}$ in wet season and from 0.46 to $131.17 \mathrm{mg} / \mathrm{kg}$ with a mean concentration of $22.12 \mathrm{mg} / \mathrm{kg}$ in the dry season.
Figures 1 and 2 showed the distribution of PAHs in the wet and dry seasons. While fluoranthene, antracene, indeno (1,2,3-cd) pyrene and dibenzo (ah)antracene were dominant in wet season with high concentration $(\geq$ $100 \mathrm{mg} / \mathrm{kg}$ ), benzo (b) fluoranthene, benzo (k) fluoranthene, benzo (a) pyrene, indeno (1,2,3-cd) pyrene and benzo (ghi) perylene were relatively higher in concentration $(\geq 2 \mathrm{mg} / \mathrm{kg})$ than the remaining 11 PAHs in the dry season. 
The concentrations of lower molecular weight PAHs (LMW, i.e., 2-3 ring PAHs) in the soot samples ranged from 0 to $3,961.3 \mathrm{mg} / \mathrm{kg}$ with mean concentration of 511.74 $\mathrm{mg} / \mathrm{kg}$ in the wet season while the concentrations of LMW PAHs in the dry season ranged from 0.12 to $7.87 \mathrm{mg} / \mathrm{kg}$ with mean concentration of $1.92 \mathrm{mg} / \mathrm{kg}$. General assessment of the descriptive statistics showed that HMW PAHs were dominant in both the seasons. Maximum values in both the wet and dry seasons showed that HMW PAHs is higher and the HMW PAHs constituted $91 \%$ of total PAHs in the dry season with $45 \%$ of total PAHs in the wet season from pyrolytic sources and the rest from petroleum origin. The concentrations of higher molecular weight PAHs (HMW, 4-6 ring PAHs) in soils ranged from ND/0 to $5,627.88 \mathrm{mg} / \mathrm{kg}$ with a mean concentration of $421.5 \mathrm{mg} / \mathrm{kg}$ in the wet season while in the dry season the concentrations ranged from 0.34 to $123.3 \mathrm{mg} / \mathrm{kg}$ with a mean concentration of $20.2 \mathrm{mg} / \mathrm{kg}$. The concentrations of PAHs in wet season were higher than those in the dry season. The mean concentration of PAHs in the wet season is 42 times (in $\mathrm{mg} / \mathrm{kg}$ ) higher than the mean concentration in dry season.

Figures 3 and 4 showed that in the wet season the highest concentration of PAHs was found was 2,432.85 $\mathrm{mg} / \mathrm{kg}$ with 3-ring PAHs accounted for $45 \%$ of this total value. Though the concentration in the dry season is relatively low compared to wet season, the highest in this dry season was still in the same location at $53.5 \mathrm{mg} / \mathrm{kg}$ concentration of which 6-ring PAHs accounted for $46 \%$ of this total. Implying that 3-ring PAHs were dominant in the wet season and 6-ring PAHs dominated the entire sampling sites in the dry season.

\begin{tabular}{|c|c|c|c|c|c|c|}
\hline Islands and bays & Medium & $\begin{array}{c}\text { Number of } \\
\text { PAHs }\end{array}$ & Season/ Others & Range & Median/mean & Reference \\
\hline \multirow{2}{*}{$\begin{array}{c}\text { Port Harcourt, Rivers } \\
\text { State Nigeria } \\
\end{array}$} & Air & 16 & Wet & $0-9,589,180$ & 933,240 & This study \\
\hline & & & Dry & $460-131,170$ & 22,120 & \\
\hline \multirow[t]{3}{*}{ Lagos Megacity, Nigerian } & Dust & & Industrial & $545-10,785$ & & \multirow{3}{*}{$\frac{\text { Iwegbue et al. }}{\underline{2020}}$} \\
\hline & & & Commercial & $289-17,943$ & & \\
\hline & & & Residential & $616-13,174$ & & \\
\hline \multirow[t]{2}{*}{ Niger Delta of Nigeria } & Soils & 16 & $\Sigma 16 \mathrm{PAH}$ & $188-684$ & \multirow[t]{2}{*}{$\mathrm{N}$} & $\frac{\text { Iwegbue } e t ~ a l, .}{2016}$ \\
\hline & & 7 & $\Sigma \mathrm{PAH}_{7 \mathrm{c}}$ & $28.5-571$ & & \\
\hline $\begin{array}{l}\text { Guizhou, Southwest of } \\
\text { China }\end{array}$ & Air & 18 & $\begin{array}{l}\text { Indoor \& } \\
\text { Outdoor }\end{array}$ & $0.0022-0.0142$ & 0.0068 & $\begin{array}{l}\text { Yang et al., } \\
2015\end{array}$ \\
\hline Vasilievsky, Russia & Soils & 11 & & $0.197-8.20$ & 1.97 & $\begin{array}{c}\text { Lodygin et al } \\
2008 \\
\end{array}$ \\
\hline Bermuda, Britain & Sediments & 13 & & $33.0-10200$ & $1910 / 1070$ & Jones, 2011 \\
\hline
\end{tabular}

$\mathrm{N}$ - No information; $\Sigma \mathrm{PAH}_{7 \mathrm{c}}$ carcinogenic PAHs

Table 2:- PAH concentrations in $\mu \mathrm{g} / \mathrm{kg}$ in Different Media and places

Table 2 showed that the total PAHs concentrations in this study is much higher than those reported by Iwegbue et al. (2016) in Niger Delta of Nigeria soils and those obtained in indoor and outdoor air of Guizhou, Southwest of China by Yang et al. (2015). The minimum PAHs concentrations in dry season in this work were in the range similar to those reported by Iwegbue et al. (2020) in industrial, commercial and residential areas of Lagos. The total PAHs concentrations in soils and sediments of Vasilievsky, Russia and Bermuda, Britain are comparatively lower than the concentrations of PAHs in this study.

\section{$>$ Potential Source of PAHs in the Study Area}

The molecular diagnostic ratios of PAHs are commonly used as a tool for the identification and characterization of PAHs emission sources and the profile and composition of the identified PAHs reflects the individual source of emission (Yunker et al., 2002 and Wang et al., 2007). PAHs can be from petrogenic or pyrogenic sources. Petrogenic PAHs are generally characterized by proportion of low molecular weight (LMW) while pyrogenic PAHs feature higher levels of high molecular weight (HMW) substance. The mass ratio of LMW/HMW has been widely introduced as a benchmark for distinguishing petrogenic from pyrogenic PAH sources (Soclo et al., 2000; De Luca et al., 2005). The ratios of LMW/HMW higher than 1 indicates the petrogenic sources (petroleum emission) and the ratios of LMW/HMW lower than 1 indicates pyrogenic (e.g. petroleum combustion)

The LMW/HMW ratios in the wet season soot ranged from 0.43 to 4.68 with a mean value of 1.39 . Seventy percent of the total samples had a ratio greater than 1 , indicating existence of petrogenic sources of PAHs (Fig. 5). On the other hand, the ratios of LMW/HMW in the dry season samples ranged from 0.02 to 1.22 with a mean value of 0.39 . Ninety percent of the total samples had a ratio less than 1 , indicating existence of pyrogenic sources of PAHs (Fig. 6).

The results of the study showed that in the wet season, the value of the parent isomeric ratio $\mathrm{Fla} /(\mathrm{Fla}+\mathrm{Pyr})$ were between 0.0 to 0.97 and the values of $\mathrm{Ant} /(\mathrm{Ant}+\mathrm{Phe})$ were between 0.0 to 0.99 while in the dry season the values of the parent isomeric ratio $\mathrm{Fla} /(\mathrm{Fla}+\mathrm{Pyr})$ were between 0.13 to 0.67 and the values of $\mathrm{Ant} /(\mathrm{Ant}+\mathrm{Phe})$ were between 0.22 to 0.83 . The cross plot of Fla/(Fla + Pyr) and Ant/(Ant + Phe) is as shown in Figure 7 indicates that the sources of PAHs in the soot during the wet season are four. The first 
and second groups constitute $55 \%$ and $17 \%$ of the sampling sites depicted the characteristics of petroleum combustion i.e., crude oil, liquid fossil fuel and automobile combustion (Figs. 7A \& 7B). The third group constituted $22 \%$ of the sampling sites with the characteristics of mixture both petroleum emission and combustion (Fig. 7C), while the remaining $6 \%$ for the fourth group (Fig. 7D) was of petroleum origin (petrogenic).
In the dry season, the cross plot of Fla/(Fla + Pyr $)$ and Ant/(Ant + Phe $)$ is as shown in Figure 8A indicated that the sources of PAHs in the soot exhibited the combustion origin with $82 \%$ grass, wood and coal combustion and the remaining $18 \%$ were of petroleum combustion (Fig. 8B). Therefore, the primary source of PAHs in Port Harcourt could be from biomass combustion.

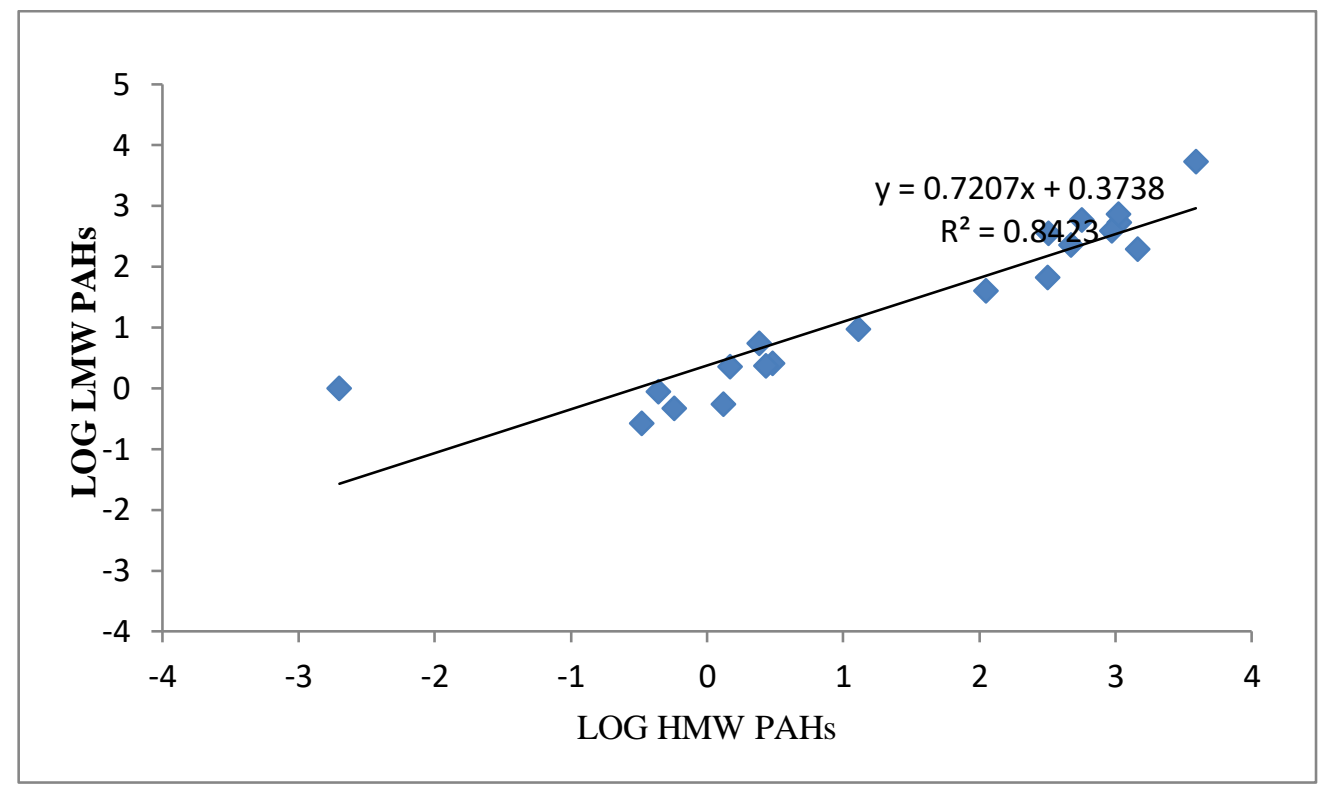

Fig 6:- The logarithmic plot of LMW and HMW PAH concentrations During Wet Season in Port Harcourt

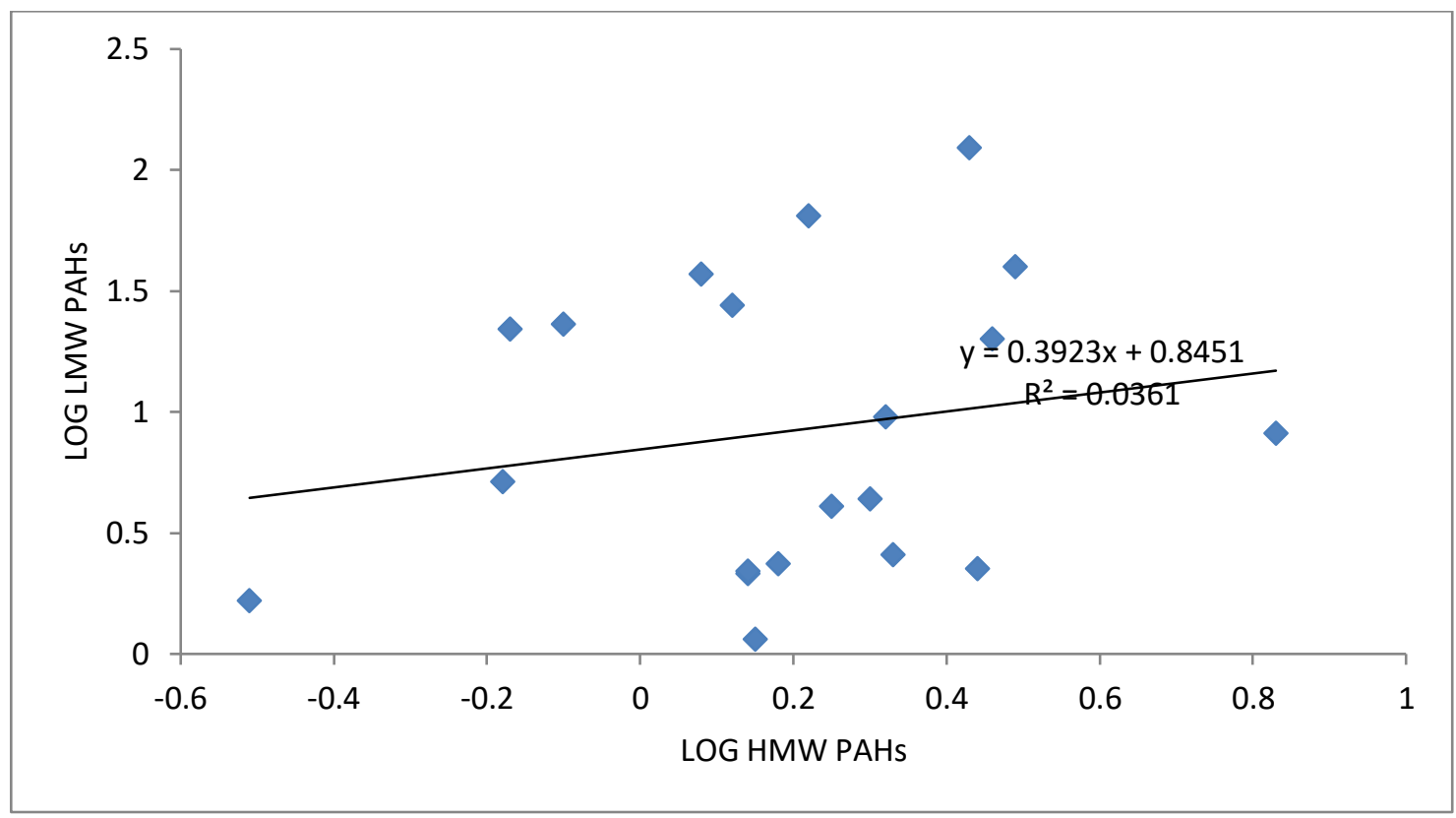

Fig 7:- The logarithmic Plot of LMW and HMW PAH Concentrations in the Dry Season 


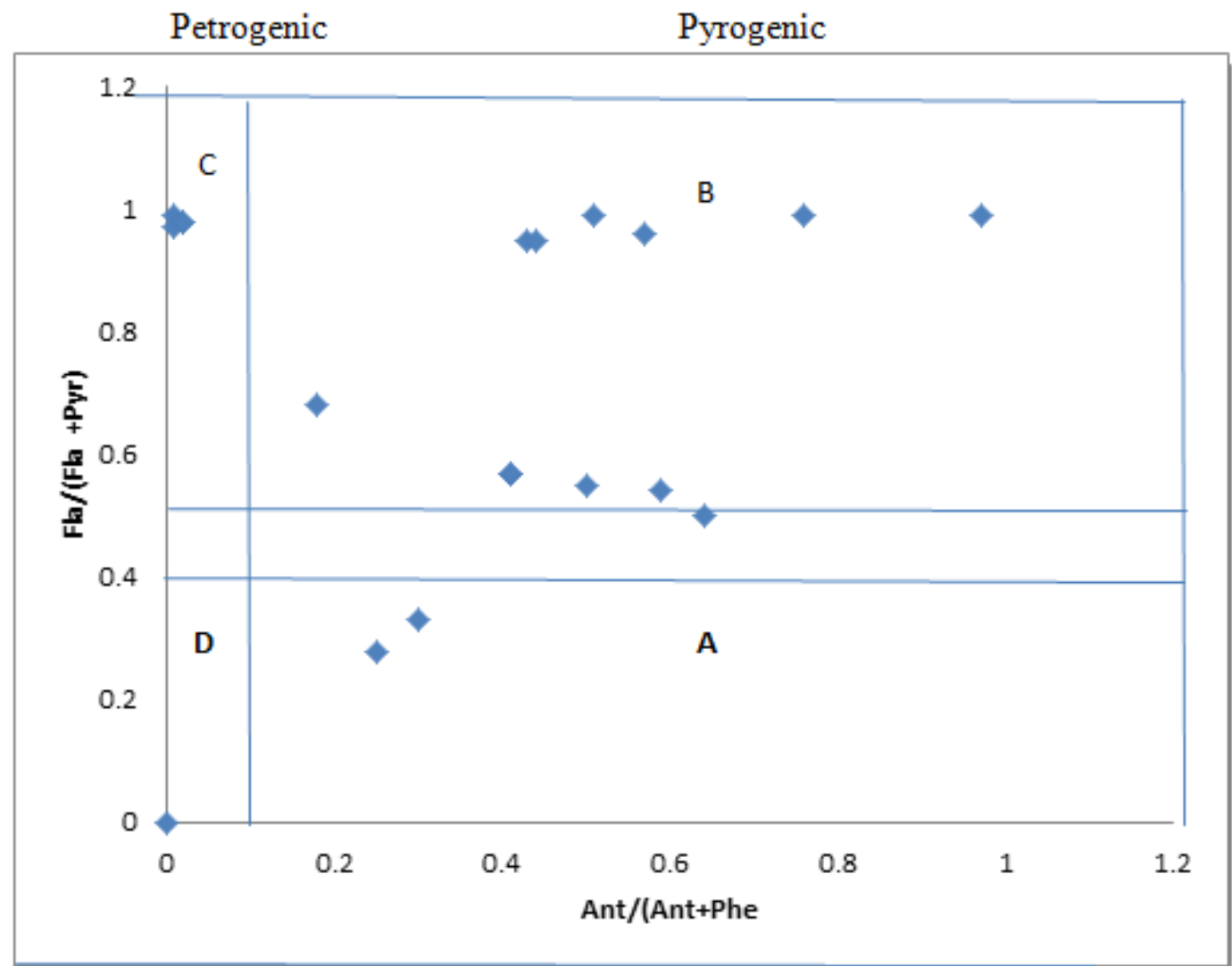

Grass, wood and coal Combustion

Petroleum Combustion

Fig 8:- Cross Plots for the Ratios of Fla/(Pyr+Fla) and Ant/(Phe+Ant) in the Wet Season Fla: fluoranthene; Pyr: pyrene; Ant: anthracene; Phe:phenanthrene

Petrogenic

Pyrogenic

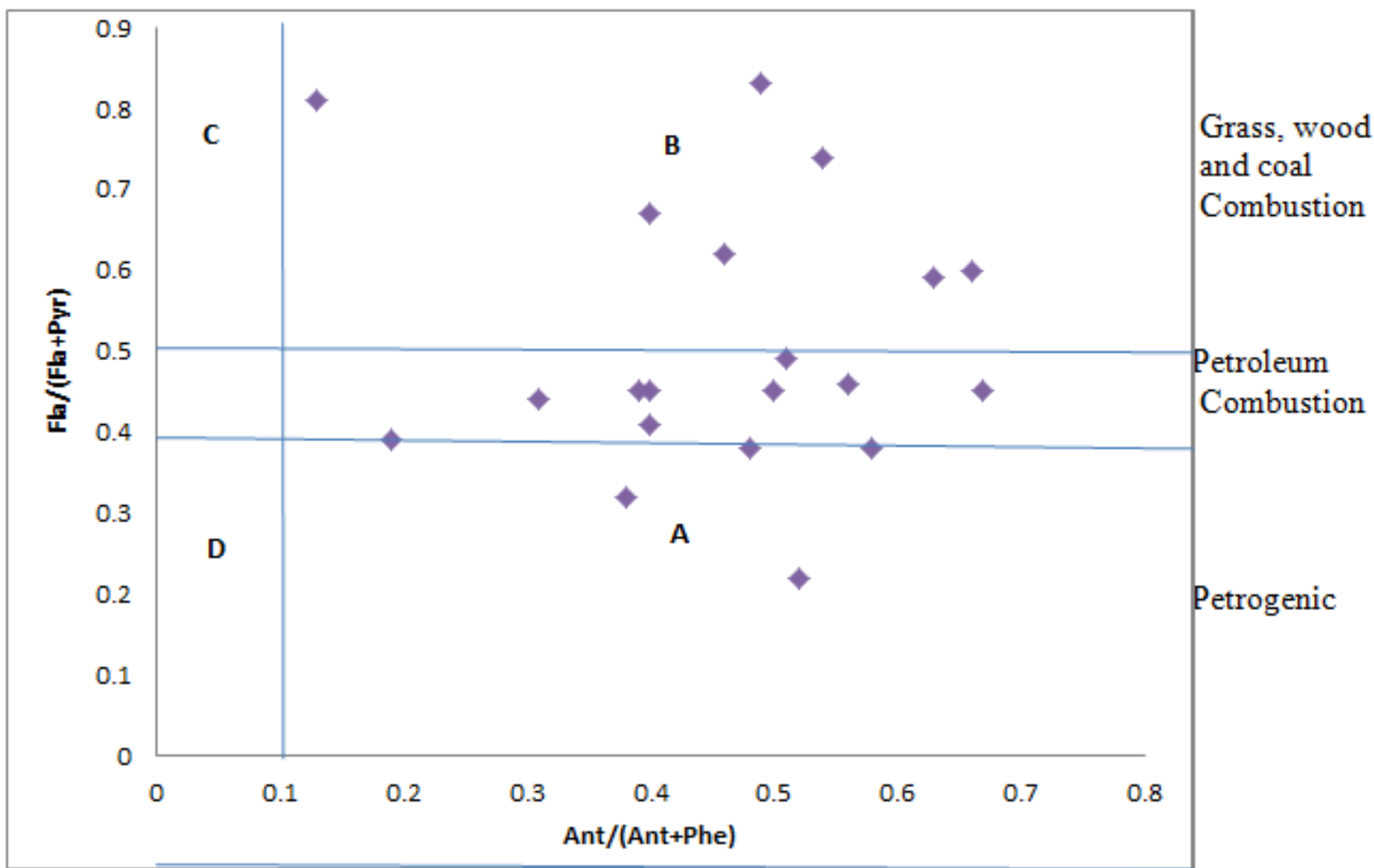

Fig 9:- Cross Plots for the Ratios of Fla/(Pyr+Fla) and Ant/(Phe+Ant) in the Dry Season Fla: fluoranthene; Pyr: pyrene; Ant: anthracene; Phe:phenanthrene 
ISSN No:-2456-2165

\begin{tabular}{|c|c|c|c|c|c|c|c|c|}
\hline \multirow[b]{2}{*}{ PAH } & \multirow{2}{*}{ Type } & \multirow{2}{*}{ TEF } & \multicolumn{3}{|c|}{ Wet Season } & \multicolumn{3}{|c|}{ Dry Season } \\
\hline & & & Minimum & Maximum & Mean & Minimum & Maximum & Mean \\
\hline Naphthalene & LMW & 0.001 & 0 & 0.00 & 0.00 & 0.00 & 0.00 & 0.00 \\
\hline Acenaphthylene & LMW & 0.001 & 0 & 0.85 & 0.08 & 0.00 & 0.00 & 0.00 \\
\hline Acenaphthene & LMW & 0.001 & 0 & 0.61 & 0.06 & 0.00 & 0.00 & 0.00 \\
\hline Flourene & LMW & 0.001 & 0 & 0.96 & 0.12 & 0.00 & 0.00 & 0.00 \\
\hline Anthracene & LMW & 0.01 & 0 & 15.03 & 2.49 & 0.00 & 0.01 & 0.00 \\
\hline Phenanthrene & LMW & 0.001 & 0 & 0.04 & 0.01 & 0.00 & 0.00 & 0.00 \\
\hline Flouranthene & HMW & 0.001 & 0 & 0.18 & 0.01 & 0.00 & 0.00 & 0.00 \\
\hline Pyrene & HMW & 0.001 & 0 & 0.71 & 0.07 & 0.00 & 0.00 & 0.00 \\
\hline Benz (a) antracene & HMW & 0.1 & 0 & 20.75 & 2.69 & 0.01 & 0.42 & 0.10 \\
\hline Chrysene & HMW & 0.01 & 0 & 0.44 & 0.04 & 0.00 & 0.07 & 0.01 \\
\hline Benzo (b) flouranthene & HMW & 0.1 & 0 & 5.03 & 0.74 & 0.01 & 2.00 & 0.23 \\
\hline Benzo (k) flouranthene & HMW & 0.1 & 0 & 3.57 & 0.67 & 0.01 & 1.94 & 0.27 \\
\hline Benzo (a) pyrene & HMW & 1 & 0 & 69.81 & 5.52 & 0.04 & 12.78 & 1.92 \\
\hline DiBenzo $(\mathrm{a}, \mathrm{h})$ antracene & HMW & 1 & 0 & 1522.00 & 100.17 & 0.00 & 6.43 & 1.02 \\
\hline Indeno (1.2.3-cd) pyrene & HMW & 0.1 & 0 & 165.30 & 11.86 & 0.00 & 3.75 & 0.68 \\
\hline Benzo (ghi) perylene & HMW & 0.01 & 0 & 11.54 & 0.72 & 0.00 & 0.14 & 0.02 \\
\hline$\Sigma \mathrm{BaP}_{\mathrm{eq}}$ & & & 0.00 & 1816.82 & 125.24 & 0.06 & 27.54 & 4.26 \\
\hline LMW & & & 0.00 & 17.49 & 2.75 & 0.00 & 0.02 & 0.01 \\
\hline HMW & & & 0.00 & 1799.33 & 122.49 & 0.06 & 27.52 & 4.26 \\
\hline
\end{tabular}

Table 3:- Cancer toxicity expressed in Berms of Benzo (a) pyrene Equivalent

TEF denotes toxic equivalency factor [33]; BaPeq denotes Bap equivalent concentration. ND: not detected.

Benzo (a) pyrene, DiBenzo (a,h) antracene and indeno (1.2.3-cd) pyrene contributed the highest toxicity with $94 \%$ and $85 \%$ in wet and dry seasons, respectively.

\begin{tabular}{|c|c|c|c|c|c|c|c|}
\hline & \multicolumn{3}{|c|}{ Wet season } & \multicolumn{3}{c|}{ Dry season } \\
\hline & Minimum & Maximum & Mean & & Minimum & Maximum & Mean \\
\hline Ingestion & $0.00 \mathrm{E}+00$ & $2.84 \mathrm{E}-03$ & $1.96 \mathrm{E}-04$ & & $9.39 \mathrm{E}-08$ & $4.31 \mathrm{E}-05$ & $6.66 \mathrm{E}-06$ \\
\hline Inhalation & $0.00 \mathrm{E}+00$ & $2.27 \mathrm{E}-07$ & $1.56 \mathrm{E}-08$ & & $7.50 \mathrm{E}-12$ & $3.44 \mathrm{E}-09$ & $5.33 \mathrm{E}-10$ \\
\hline Dermal contact & $0.00 \mathrm{E}+00$ & $4.87 \mathrm{E}-01$ & $3.35 \mathrm{E}-02$ & & $1.61 \mathrm{E}-05$ & $7.38 \mathrm{E}-03$ & $1.14 \mathrm{E}-03$ \\
\hline Total ILCRs & $0.00 \mathrm{E}+00$ & $4.90 \mathrm{E}-01$ & $3.37 \mathrm{E}-02$ & & $1.62 \mathrm{E}-05$ & $7.42 \mathrm{E}-03$ & $1.15 \mathrm{E}-03$ \\
\hline
\end{tabular}

Table 4:- Descriptive Statistics of Seasonal Incremental Lifetime Cancer Risks (ILCR) Data in Soot PAHs in Port Harcourt 
Mean ILCR in wet season $3.37 \times 10^{-2}\left(33,700 \times 10^{-6}\right)$ meaning 1 in every 30 persons in the study area is estimated to develop cancer. In the dry season, mean ILCR is $1.15 \times 10^{-3}\left(1,150 \times 10^{-6}\right)$ meaning 1 in every 870 persons in the study area is estimated to develop cancer.

\section{Cancer Risk Assessment in Port Harcourt}

Total benzo (a) pyrene equivalent $\left(\mathrm{BaP}_{\mathrm{eq}}\right)$ of all the 16 USEPA priority pollutant PAHs was used. This the addition of each PAH toxicity equivalent (TEQ) which in turn is the product of concentration of $\mathrm{PAH}$ and its toxicity equivalent factor (TEF).

The results of this study showed that the total benzo (a) pyrene equivalent $\left(\mathrm{BaP}_{\mathrm{eq}}\right)$ of $16 \mathrm{PAHs}$ in the samples of soot ranged from 0 to $1,816.52 \mathrm{mg} / \mathrm{kg}$ with the mean value of $125.24 \mathrm{mg} / \mathrm{kg} \mathrm{BaP}$ eq in the wet season while the total $\mathrm{BaP}_{\mathrm{eq}}$ of $16 \mathrm{PAHs}$ in the dry season were in the range of 0.06 and $27.54 \mathrm{mg} / \mathrm{kg}$ with the mean value of $4.26 \mathrm{mg} / \mathrm{kg}$ $\mathrm{BaP}_{\text {eq. }}$

Out of the 16 PAHs, benzo (a) pyrene, dibenzo (a,h) antracene and indeno (1,2,3-cd) pyrene contributed highest cancer toxicity. These three PAHs contributed $94 \%$ of the total toxicity with the highest of this from Dibenzo $(\mathrm{a}, \mathrm{h})$ antracene. Similarly, in the dry season these three PAHs (BaP, DahA and IcdP) accounted for $85 \%$ of the cancer toxicity out of the 16 PAHs with the highest contribution from benzo (a) pyrene. Using benzo (a) pyrene (BaP) which is an established marker of PAHs in the atmosphere, there is a pervasive pollution of PAHs in the study area as mean and maximum BAP concentrations in the wet season were $5.52 \mathrm{mg} / \mathrm{kg}\left(1.5 \mathrm{ng} / \mathrm{m}^{3}\right)$ and $69.81 \mathrm{mg} / \mathrm{kg}\left(18.8 \mathrm{ng} / \mathrm{m}^{3}\right)$, respectively greater than European Union guideline target value of $1 \mathrm{ng} / \mathrm{m}^{3}$. Similarly, $20 \%$ of the samples in the dry season had $\mathrm{BaP}$ concentrations greater than this standard with maximum value of $12.78 \mathrm{mg} / \mathrm{kg}(3.5 \mathrm{ng} / \mathrm{m} 3)$ where the maximum values were recorded.

Incremental lifetime cancer risk (ILCR) is a numerical value calculated and used to assess human health risk. ILCR value greater than 10-6 indicates a potential risk i.e., receptors are unsafe from cancer due to the intake of contaminant under consideration. Table 4 shows the ILCR values calculated in the soot in Port Harcourt covering the three main exposure pathways which are inhalation, ingestion and dermal contact. The total ILCR values ranged from 0 to $4.9 \times 10-1$ with mean value of $3.37 \times 10-2$ in the wet season and the total ILCR values in the dry season ranged from $1.62 \times 10-3$ to $7.42 \times 10-3$ with mean value of $1.15 \times 10-3$. These values (> 10-6) indicate high human health risk of cancer from the exposure to soot emission in Port Harcourt. Similar, high ILCRs were also observed by Olawoyin et al. (2014) in the Niger delta water and soil. In their report, the cumulative ILCR from the water and soil contaminations were found to be $1.13 \times 10-4$ and $6.42 \times 10-4$ for children, while values of $1.09 \times 10^{-4}$ and $6.19 \times 10^{-4}$ were determined for adult.
These seasonal mean value of ILCRs of $3.37 \times 10^{-2}$ and $1.15 \times 10^{-3}$ for wet and dry seasons for estimated 33,700 and 1,150 persons per million to develop cancer. This further means that the mean ILCR in wet season $3.37 \times 10^{-2}$ $\left(33,700 \times 10^{-6}\right)$ implies 1 in every 30 persons in the study area was estimated to develop cancer. In the dry season, mean ILCR is $1.15 \times 10^{-3}\left(1,150 \times 10^{-6}\right)$ meaning 1 in every 870 persons in the study area was estimated to develop cancer.

\section{CONCLUSIONS}

The total PAHs concentrations ranged from 0 to $5,627.88 \mathrm{mg} / \mathrm{kg}$ with the mean value of $421.5 \mathrm{mg} / \mathrm{kg}$ in the wet season and PAHs concentrations ranged from 0.46 to $131.17 \mathrm{mg} / \mathrm{kg}$ with mean value of $22.12 \mathrm{mg} / \mathrm{kg}$ in the dry season. Wet season soot had a higher $\Sigma 16$ PAHs concentration than the concentration in the dry season. In these two seasons, the HMW PAHs are predominant with $\mathrm{BaP}$, DahA and IcdP accounted for over $80 \%$ of the total PAHs in both seasons. The PAHs profile and diagnosis in the study area showed that the soot is primarily from pyrogenic source characterised with petroleum combustion i.e., crude oil, liquid fossil fuel, automobile and biomass combustion. A smaller proportion were attributed to petroleum emissions (petrogenic). High concentration of soot PAHs indicate pervasive pollution of the area coupled with high benzo (a) pyrene equivalent and benzo (a) pyrene concentrations higher than European Union (2001) guideline value of $1 \mathrm{ng} / \mathrm{m}^{3}$. The mean incremental lifetime cancer risks (ILCRs) of PAHs showed that people in the research area are exposed to high carcinogenic risk with probability of 1 incidence of cancer in every 30 persons in the wet season and 1 incidence of cancer in 870 persons in the dry season. The results of this study showed the need for management strategies to address, control and regulate the levels and sources of soot emissions in Port Harcourt. It has also provided information for all stakeholders including policy makers for improving the environment and human health.

\section{REFERENCES}

[1]. Abdel-Shafy, H. I, \& Mansour, S. M. (2016). A review on polycyclic aromatic hydrocarbons: Source, environmental impact, effect on human health and remediation. Egyptian Journal of Petroleum. Volume 25, Issue 1, Pages 107-123.

[2]. De La Torre-Roche, R.J., Lee, W. Y. \& Campos-Díaz, S.I. (2009). Soil-borne polycyclic aromatic hydrocarbons in El Paso, Texas: analysis of a potential problem in the United States/Mexico border region. Journal of Hazardous Materials 163, 946-958.

[3]. Ede, P.N. \& Edokpa, D.O. (2015). Regional Air Quality of the Nigeria's Niger Delta. Open Journal of Air Pollution 4, 7-15.

[4]. Ede, P. N. \& Edokpa, D. O. (2017). Satellite determination of particulate load over Port Harcourt during black soot incidents. Journal of Atmospheric Pollution. 5 (2). 
[5]. European Commission, 2001. Ambient air pollution by Polycyclic aromatic hydrocarbon (PAHs) Position paper. Office of Official publications of the European Communities, Luxembourg.

[6]. Iwegbue, C. M. A., Obi, G., Aganbi, E., Ogala, J. E., Omo-Irabor, O. O. \& Bice S. Martincigh. B. S. (2016). Concentrations and health risk assessment of Polycyclic aromatic hydrocarbons in Soils of an urban environment in the Niger Delta, Nigeria. Toxicology and Environmental Health Sciences volume 8, pages221-233.

[7]. Iwegbue, C. M. A., Ehigbor, M. J., Tesi, G. O., Eguavoen, O. I. \& Bice S. Martincigh, B. S. (2020). Occurrence, Sources and Exposure Risk of Polycyclic Aromatic Hydrocarbons (PAHs) in Street Dusts from the Nigerian Megacity, Lagos. https://doi.org/10.1080/10406638.2020.1716027.

[8]. Jones, R. J. (2011). Spatial patterns of chemical contamination (metals, PAHs, PCBs, PCDDs/PCDFS) in sediments of a non-industrialized but densely populated coral atoll/small island state (Bermuda). Marine Pollution Bulletin 62: 1362-1376.

[9]. Kamal, A., Syed, J. H., Li J., Zhang, G., Mahmood, A. and Malik, R. N. (2016). Profile of Atmospheric PAHs in Rawalpindi, Lahore and Gujranwala Districts of Punjab Province, Pakistan. Aerosol and Air Quality Research, 16: 1010-1021.

[10]. Lodygin, E. D., Chukov, S. N., Beznosikov, V. A. and Gabov, D.N. (2008). Polycyclic aromatic hydrocarbons in soils of Vasilievsky Island (St. Petersburg). Eurasian Soil Science 41: 1321-1326.

[11]. Niranjan and Thakur (2017). The Toxicological Mechanisms of Environmental Soot (Black Carbon) and Carbon Black: Focus on Oxidative Stress and Inflammatory Pathways. Front Immunol. 2017; 8: 763. doi: 10.3389/fimmu.2017.00763 PMCID: PMC5492873. PMID: 28713383.

[12]. Nisbet, C. and Lagoy, P. (1992). Toxic Equivalency Factors (TEFs) for Polycyclic Aromatic Hydrocarbons (PAHs). Regul. Toxicol. Pharm. 16: 290-300.

[13]. Olawoyin, R., Grayson, R. L. and Okareh, O. T. (2012). Eco-toxicological and Epidemiological Assessment of Human Exposure to Polycyclic Aromatic Hydrocarbons in the Niger Delta, Nigeria. The Korean Society of Environmental Risk Assessment and Health Science and Springer. DOI 10.1007/s13530-012-0133-6.

[14]. Omidvarborna, H., Kumar, A. and Shikkim, D. (2015). Recent studies on soot modelling for diesel combustion, Renewable and Sustainable Energy Reviews. 48: 635-647.

[15]. Peng C, Chen WP, Liao XL, Wang ME, Ouyang ZY, et al. (2011) Polycyclic aromatic hydrocarbons in urban soils of Beijing: Status, sources, distribution and potential risk. Environmental Pollution 159: 802808.

[16]. Pies, C., Hoffmann, B., Petrowsky, J., Yang, Y., Ternes, T.A., Hofmann, T., 2008. Characterization and source identification of polycyclic aromatic hydrocarbons (PAHs) in river bank soils. Chemosphere 72, 1594-1601.
[17]. Tobiszewski, M. and Namiesnik, J. (2012). PAH diagnostic ratios for the identification of pollution emission sources. Environ Pollut 162:110-119.

[18]. USEPA (1993) Provisional Guidance for Quantitative Risk Assessment of PAHUS Environmental Protection Agency (1993) EPA/600/R-93/089.

[19]. Wang Z, Chen JW, Qiao XL, Yang P, Tian FL, et al. (2007) Distribution and sources of polycyclic aromatic hydrocarbons from urban to rural soils: A case study in Dalian, China. Chemosphere 68: 965971.

[20]. Yang, Q., Chen, H. and Li, B. (2015). Polycyclic Aromatic Hydrocarbons (PAHs) in Indoor Dusts of Guizhou, Southwest of China: Status, Sources and Potential Human Health Risk. PLoS ONE 10(2): e0118141. doi:10.1371/journal.pone.0118141. Maosheng Yao, Peking University, CHINA. 